\title{
Constitutional Obligation of a State to Compensate for Damage Sustained by Victims of Crimes
}

\author{
Vladislav Yu. Panchenko \\ and Anastasia E. Mikhaleva* \\ Siberian Federal University \\ 79 Svobodny, Krasnoyarsk, 660041, Russia
}

Received 05.03.2018, received in revised form 24.05.2018, accepted 31.05.2018

\begin{abstract}
The paper deals with Article 52 of the Russian Constitution, which obliges the state to provide a compensation for damage sustained by victims of crimes. On the one hand, many lawyers believe that nowadays positive obligations of the state under this Article are limited to creation of necessary legislative and enforcing mechanisms, which ensure asset tracing, attachment of property and other conditions to guarantee compensation for a damage caused by a guilty person. On the other hand, in the authors'view, Article 52 of the Constitution of the Russian Federation has its own implication, raising a question of possible ways to restore justice in cases where the state is not an offender itself, but no one else would compensate a victim. This position takes into account the best international practices and pressing social need of a democratic society. However, consecutive application of different interpretation techniques allows to conclude that this norm sets out an illusory right, since the legislation in force contains no mechanisms for its observance. Such situation undermines the significance of the Constitution as a fundamental act having the supreme juridical force. As a result, three possible alternatives can be suggested as a way out: to amend the text of the Constitution of the Russian Federation by exclusion of the ambiguous provision; to rely on direct action of the Constitution of the Russian Federation in law enforcement; to adopt the law specifying the procedure by which compensation shall be paid to victims of crimes for sustained damage. Thus, the issue of Article 52 implementation requires immediate legal solution on the highest political level.
\end{abstract}

Keywords: constitutional rights and freedoms, legal guarantees, positive obligations, compensation for damage sustained by victims of crimes.

The article was prepared under the financial support of the grant of the President of the Russian Federation No. MD-721.2018.6.

DOI: 10.17516/1997-1370-0284.

Research area: law.

Introduction. According to Article 52 abuse of office shall be protected by law. The of the Constitution of the Russian Federation State shall provide access to justice for them (1993), "the rights of victims of crimes and of and a compensation for sustained damage".

(c) Siberian Federal University. All rights reserved

* Corresponding author E-mail address: panchenkovlad@mail.ru; mihaleva_anastas@mail.ru 
While the first part of the abovementioned quotation is unequivocal, positive constitutional obligation of the Russian Federation to "provide a compensation for sustained damage" raises various questions.

\section{Linguistic analysis of Article 52 of the} Constitution of the Russian Federation. The word "to provide" has multiple meanings in Russian language. However, it is not defined by legislation in force. Dictionaries interpret this term as "a set of measures and tools, formation of conditions that facilitate normal economic development, achievement of projected goals" (Rizenberg, Lozovsky, 1999); "those things which a person, a corporation or a state, etc. gives in necessary amount or guarantees" (Dmitriev). Therefore, the most common meaning of the term "to provide" reflects different mechanisms of essential support in obtaining necessary results to satisfy basic interests.

Article 42 of the Criminal Procedure Code of the Russian Federation states that "seen as the victim shall be a natural person, upon whom a physical, property or moral damage was inflicted by the crime, as well as a legal entity, if his property and business reputation were damaged by the crime". It focuses on procedural aspects of victim's status, since "the decision on recognizing a person to be a victim shall be formalized by the resolution of the inquirer, investigator or prosecutor, or of the court".

Meanwhile, the Constitutional Court of the Russian Federation ruled that the words and phrases in the Constitution of the Russian Federation should be interpreted not in the context of a narrow statutory definition, but in their constitutional sense. For example, explaining the application of Article 48 (2) of the Constitution of the Russian Federation (the right to receive assistance of a lawyer (counsel for the defense)), the Constitutional Court of the Russian Federation has not limited the terms "person detained", "taken into custody", "accused of committing a crime" to procedural status. It has insisted on taking into account factual characteristics of a prosecuted person (Judgement of the Constitutional Court of the Russian Federation..., 2000).

Similar approach can be applied to describe the figure of a victim, who actually de facto becomes a participant of the proceedings as soon as it is established that he / she (1) has suffered (2) from a crime which (3) caused this harmful consequences.

Another ambiguity lays in such terminological collocation as "compensation for sustained damage".

On the one hand, it is necessary to clarify whether the Constitution drafters intended to establish some kind of special instrument, requiring additional legal framework for its implementation and applicable in particular cases (similar to the compensation for excessively lengthy proceedings), or a general remedy (including damages, restoration of the situation, which existed before the given right was violated, etc.).

On the other hand, there is a difficulty concerning the interpretation of the concept of "damage", since no unified approach exists either in theory or in practice (Russian Civil Law..., 2014). In particular, it is not clear whether "sustained damage" covers only economic losses or emotional distress as well.

\section{Historical analysis of Article 52 of} the Constitution of the Russian Federation. A research into the projects of the Constitution of independent Russia, which were drafted after the USSR collapsed, allows to conclude that the majority of texts did not contain similar collocations connected to compensation:

a) the Commission of the Congress of People's Deputies of the Russian Federation did not include special provisions about victims 
in the Chapter under the title "Guarantees and Protection of Rights and Freedoms". Indeed, Article 43 of the constitutional project provided: "Everyone shall have the right to compensation for sustained damage, illegally inflicted to his health, honour and reputation as well as property. Damage caused by unlawful actions of bodies of state authority and their officials shall be compensated by the State" (Proekt Konstitutsii Rosiiskoi Federatsii, podgotovlennyi Konstitutsionnoi Komissiei...). Thus, under this draft positive obligations of the State ought to be limited to particular cases;

b) the project prepared by S. Alexeev and A. Sobchak under the decision of the Political Council of Russian movement for Democratic Reformations did not mention this issue even in the chapter, devoted to safeguards for the rights and freedoms of the citizens (Proekt Konstitutsii Rosiiskoi Federatsii, podgotovlennyi po resheniyu Politsoveta...);

c) the text of the Constitution of the Russia Soviet Federation contained rather accurate provision that "the State guarantees protection for the rights of victims of crimes and of abuse of office" (Article 44) (Proekt Konstitutsii Rossiiskoi Federatsii, podgotovlennyi gruppoi narodnykh deputatov...).

However, the draft of the group presided by S. Shahray stated the rule similar to the legislation in force (in Article 32) (Proekt Konstitutsii Rossiiskoi Federatsii, podgotovlennyi rabochei gruppoi pod rukovodstvom Shakhraia S.M. ...). At the same time the most interesting project of the Constitution (Fundamental Law) of the Russian Federation was suggested by the former President of the Russian Federation, where Article 32 declared that "the State provides $<\ldots>$ a compensation for sustained damage either at perpetrator's or state's expense" (Proekt Konstitutsii (Osnovnogo zakona) Rossiiskoi Federatsii...).

\section{Logical analysis of Article 52 of the} Constitution of the Russian Federation. Despite the fact that the words "victims of crimes and of abuse of office" has the purpose of defining the circle of eligible persons (excluding from the scope of compensatory mechanism victims of minor offenses and torts), the conjunction between the generic concept (crimes) and the subordinate concept (abuse of office) does not seem to be a correct juridical technique.

The choice of such terminology was determined by at least two circumstances: (1) adoption of the Declaration of Basic Principles of Justice for Victims of Crime and Abuse of Power by the General Assembly of the United Nations on 29 November 1985, which uses similar wording (Declaration of Basic Principles of Justice for Victims of Crime and Abuse of Power...); (2) development of the general policy against corruption, seeking to emphasize the significance of this issue for the Russian Federation due to ideological and political reasons (similar to Article 36 of the Constitution of the Russian Federation that sets forth the right to possess land as private property, which is already guaranteed by Article 35 of the Constitution of the Russian Federation, stating that the right of private property in general shall be protected by law).

Moreover, the second sentence of Article 52 of the Constitution of the Russian Federation sets forth that "the State shall provide $<\ldots>$ for victims of crimes a compensation for sustained damage", i. e. (a) the circle of victims is not limited to those who suffered from particular offenses; and (b) the article as a whole covers victims of all crimes, not only victims of abuse of office.

Therefore, it seems illogical to claim that Article 52 does not imply the possibility of compensation in cases different from the abuse of office (Kommentarii k Konstitutsii Rossiiskoi Federatsii...). 
IV. Systematic analysis of Article 52 of the Constitution of the Russian Federation. If application of Article 52 was limited to the abuse of office cases, it would be completely identical to Article 53 of the Constitution of the Russian Federation.

The Russian Federation guarantees compensation for damage resulting from the abuse of office, since under international law actions of bodies of state authority and their officials are attributed to the state itself (Draft Articles on Responsibility of States for Internationally Wrongful Acts...).

The principle of statutory economy and internal systematic connections within law make it impossible for fundamental act, having the supreme juridical force, to contain any repetitions. Consequently, Article 52 of the Constitution of the Russian Federation has another implication, raising a question of possible ways to restore social justice in cases where the state is not an offender itself, but no one else would compensate a victim.

\section{Functional analysis of Article 52 of} the Constitution of the Russian Federation. It is important to reveal the purposes that predetermined the inclusion of a compensation rule into constitutional provisions.

Many lawyers believe that nowadays positive obligations of the state under this Article are limited to creation of necessary legislative and enforcing mechanisms, which ensure asset tracing, attachment of property and other conditions to guarantee compensation for a damage caused by a guilty person (Kommentarii k Konstitutsii Rossiiskoi Federatsii...). This position justifies current situation in Russian law making and law enforcement practices.

However, such measures represent independent guarantees that are stipulated by other constitutional provisions (including Article 45 - "state protection of the rights and freedoms of man and citizen shall be guaranteed", Article 46 - "everyone shall be guaranteed judicial protection of his rights and freedom', etc.).

Therefore, Article 52 may be described as a "dead" legal norm, which declares the right, but ignores particular mechanisms of its observance. This conclusion is supported directly or indirectly by the following facts:

- the abovementioned wording of the provision suggested by the former President of the Russian Federation, which specified the source by which a compensation shall be provided for victims ("either at perpetrator's or state's expense") (Proekt Konstitutsii (Osnovnogo zakona) Rossiiskoi Federatsii...);

- Article 30 (3) of the Law of the Russian Soviet Federative Socialist Republic on 24 December 1990 № 443-1, stipulating that "damage inflicted to an owner is compensated by the state on the grounds of the court order", "state expenses shall be collected from the offender according to procedural rules of the Russian Soviet Federative Socialist Republic" (Law of RSFSR on 24 December 1990 № 443-1...);

- draft of the Federal Law "On the victims of crimes" prepared by the Investigation Committee of the Russian Federation and published on 24 February 2012, but not implemented yet (Proekt Federal'nogo zakona...). In this project Article 4 states the right of victims to "receive fair and reasonable reimbursement for damage caused by the crime and (or) state compensation", whereas Chapter 2 contains detailed description of compensation procedure, including establishment of the public extra-budgetary Federal Victims Relief Fund.

Conclusion. In our view, the abovementioned problem shall not be left unsolved and the following alternatives are to be considered:

1. Amendments to the text of the Constitution of the Russian Federation by exclusion of the ambiguous provision. 
This way might be chosen as a priority only if it is deemed impossible for the state to compensate the damage sustained by victims of crimes.

For example, in the majority of the constitutions of the former Soviet Union (except for the Constitution of the Tajik Republic on 6 November 1994, where Article 21 sets forth that "the state guarantees to a victim judicial protection and reimbursement of the inflicted damage") this issue (state obligations in relation to the rights of victims of any crimes) is treated differently:

a) the problem of compensation is not covered at all (in particular, in the Constitution of the Republic of Kazakhstan on 30 August 1995, the Constitution of the Republic of Kyrgyzstan on 27 June 2010, the Constitution of the Republic of Moldova on 29 July 1994, the Constitution of the Republic of Turkmenistan on 27 December 1995, the Constitution of the Republic of Uzbekistan on 8 December 1992, the Constitution of the Ukraine on 28 June 1996);

b) the problem of compensation is described in clearer and more understandable words:

- Article 68 of the Constitution of the Republic of Azerbaijan on 12 November 1995 sets forth that "rights of the person suffered from crime and also from usurpation of power are protected by law", "suffered person has the right to take part in administration of justice and demand for compensation of losses";

- Article 20 of the Constitution of the Republic of Armenia on 5 July 1995 contains a blanket rule, stating that "all damages incurred by the victim shall be compensated in conformity with the procedure prescribed by the law";

- Article 59 of the Constitution of the Republic of Belarus on 15 March 1994 mentions that "the State shall take all measures at its disposal to create the domestic and international order necessary for the exercise in full of the rights and liberties of the citizens".
Thus, all these doubts might be eliminated by exclusion of the analyzed rule from Article 52 of the Constitution of the Russian Federation that would become rather radical solution. The reason lies in Article 135 of the Constitution of the Russian Federation, according to which provisions of Chapter $\underline{2}$ (including Article 52) may not be revised by the Federal Assembly, i. e. such a proposal is identical to initiative to adopt a new Constitution of the Russian Federation.

2. Direct action of the Constitution of the Russian Federation in law enforcement.

Undoubtedly, Article 15 of the Constitution of the Russian Federation contains a rule about its direct action. Some scholars believe that if a constitutional provision has no express reference to other statutes, all subjects of the constitutional law (including courts) must directly apply it, regardless of existence or absence of specified acts (Bol'shoi yuridicheskii slovar'...).

However, such doctrinal conclusions are hardly relevant to real practice.

Firstly, in one of its judgements the Supreme Court of the Russian Federation explained that the court in the course of proceedings can directly apply the Constitution, when constitutional provisions do not suppose additional regulation (Judgement of the Plenum of the Supreme Court of the Russian Federation on 31 October 1995...).

However, Article 52 of the Constitution of the Russian Federation clearly requires special legal mechanism to perform this obligation, determining the procedure by which a compensation shall be provided, terms, measures, responsible persons, etc.

Secondly, even if a court hypothetically issued this remedy to a claimant, this decision would be unenforceable due to the absence of economic (financial) mechanism, allowing such ways of budget money expenditure. 
3. Adoption of the law specifying the procedure by which compensation shall be paid to victims of crimes for sustained damage.

Creation of enforcement mechanism for Article 52 of the Constitution of the Russian Federation and necessary institutional changes will allow to overcome current misleading situation, preserving the stability of the Constitution and following the best practices in respect of the rights of crime victims:

- on the international level, where the leading position was formulated in the UN Declaration of Basic Principles of Justice for Victims of Crime and Abuse of Power (1985). Moreover, the attempt to strengthen the position of crime victims is apparent within international courts of law. For instance, the International Criminal Court became the first tribunal to provide crime victims with a full procedural status and guarantee compensation for sustained damage through special monetary fund even when an offender is unable to pay (Rome Statute of the International Criminal Court...);

- on the national level of foreign countries. The right of crime victims to receive compensation is guaranteed by the US legislation (coverage of medical expenses, lost income, etc.) (42 U. S. Code...). The European Union has also adopted a special Directive that establishes minimal standards of the rights, support and protection of crime victims (Directive 2012/29/eu...), encouraging the states to develop public compensatory mechanisms. For example, such recommendations are implemented in the Republic of Estonia, where this issue is administered by the Ministry of Social Affairs and compensation itself is paid to direct and indirect victims of violent crimes at expense of the specially created Fund.

All in all, the Constitution of the Russian Federation contains a declaratory provision concerning the obligation of the state to provide a compensation to victims of crimes for sustained damage. This situation undermines public trust to the fundamental act of the supreme juridical force and adversely affects the state's image. Therefore, the issue of Article 52 implementation requires immediate legal solution on the highest political level.

\section{References}

42 U. S. Code $§ 106602$ Crime victim compensation, available at: https://www.law.cornell.edu/ uscode/text/42/10602 (retrieved 11 February 2018).

Bol 'shoi yuridicheskii slovar’ [Big Law Dictionary], available at: http://jurisprudence.academic. ru/4045/непосредственное_действие_конституции (retrieved 11 February 2018).

Declaration of Basic Principles of Justice for Victims of Crime and Abuse of Power (29 November 1985), available at: http://www.un.org/ru/documents/decl_conv/declarations/power. shtml (retrieved 11 February 2018).

Directive 2012/29/eu of the European Parliament and of the Council of 25 October 2012 establishing minimum standards on the rights, support and protection of victims of crime, and replacing Council Framework Decision 2001/220/JHA, available at: http://eur-lex.europa.eu/LexUriServ/LexUriServ.do? uri=OJ:L:2012:315:0057:0073:EN:PDF (retrieved 11 February 2018).

Dmitriev, D.V. Tolkovyi slovar' russkogo iazyka [Dictionary of the Russian language with definitions], available at: http://dic.academic.ru/dic.nsf/dmitriev/2920 (retrieved 11 February 2018).

Draft Articles on Responsibility of States for Internationally Wrongful Acts with commentaries, available at: http://legal.un.org/ilc/texts/instruments/English/commentaries/9_6_2001.pdf(retrieved 11 February 2018). 
Hallik, L. State Compensation for Victims of Crimes in Estonia, available at: https://www.tm.gov. lv/files/.../Riga22052012Hallik_en.pdf (retrieved 11 February 2018).

Judgement of the Constitutional Court of the Russian Federation on 27 June 2000 № 11-P "Po delu o proverke konstitutsionnosti polozhenii chasti pervoi stat'i 47 i chasti vtoroi stat'i 51 Ugolovno-processual'nogo kodeksa RSFSR v svyazi s zhaloboi grazhdanina V.I. Maslova" [On the case concerning the review of Article 47 (1) and Article 51 (2) of the Code of Criminal Procedure of RSFSR in relation to the V.I. Maslov's application], available at: http://www.consultant.ru (retrieved 11 February 2018).

Judgement of the Plenum of the Supreme Court of the Russian Federation on 31 October 1995 № 8 "O nekotorykh voprosakh primeneniya sudami Konstitutsii Rossiiskoi Federatsii pri osuschestvlenii pravosudia" ["On some issues of application of the Constitution of the Russian Federation by courts in course of law enforcement"], available at: http://www.consultant.ru (retrieved 11 February 2018).

Kommentarii $k$ Konstitutsii Rossiiskoi Federatsii [Commentary to the Constitution of the Russian Federation] / ed. by L.V. Lazarev (2009). Moscow, Novaia provovaia kul tura, available at: http:// constitution.garant.ru/science-work/comment/5366634/chapter/2// (retrieved 11 February 2018).

Law of RSFSR on 24 December 1990 № 443-1 “O sobstvennosti v RSFSR' [On the property in RSFSR], available at: http://www.consultant.ru (retrieved 11 February 2018).

Proekt Federal nogo zakona "O poterpevshikh ot prestuplenii" [Project of Federal law "On the crime victims”], available at: https://rg.ru/2012/02/24/poterpevshie-site-dok.html (retrieved 11 February 2018).

Proekt Kostitutsii (Osnovnogo zakona) Rossiiskoi Federtsii, predstavlennyi Prezidentom Rossiiskoi Federtsii [Project of the Constitution (Fundamental law) of the Russian Federation suggested by the President of the Russian Federation], available at: http://constitution.garant.ru/ history/active/1021/ (retrieved 11 February 2018).

Proekt Kostitutsii Rossiiskoi Federtsii podgotovlennyi gruppoi narodnykh deputatov Rossiiskoi Federatsii [Project of the Constitution of the Russian Federation prepared by the group of People's Deputies of the Russian Federation], available at: http://constitution.garant.ru/history/active/1020/ (retrieved 11 February 2018).

Proekt Kostitutsii Rossiiskoi Federtsii podgotovlennyi komissiei Syezda narodnykh deputatov Rossiiskoi Federatsii [Project of the Constitution of the Russian Federation prepared by the Constitutional Commission of the Congress of People's Deputies], available at: http://constitution. garant.ru/history/active/101201/ (retrieved 11 February 2018).

Proekt Kostitutsii Rossiiskoi Federtsii podgotovlennyi po resheniyu Politsoveta Rossiiskogo Dvizheniya demokraticheskikh reform [Project of the Constitution of the Russian Federation prepared under decision of Political Council of Russian Movement for Democratic Reformations], available at: http://constitution.garant.ru/history/active/101203/\#sub_para_N_234412 (retrieved 11 February 2018).

Proekt Kostitutsii Rossiiskoi Federtsii podgotovlennyi rabochei gruppoi pod rukovodstvom Shakhraia S.M. [Project of the Constitution of the Russian Federation prepared by the working group headed by Shakhrai S.M.], available at: http://constitution.garant.ru/history/active/101202/ (retrieved 11 February 2018).

Rizeberg, B.A., Lozovsky, L.Sh., Starodubtseva, E.B. (1999). Sovremennyi Economicheskii Slovar' [Modern Economic Dictionary]. Moscow, INFRA-M, available at: http://dic.academic.ru/dic. nsf/econ_dict/18683 (retrieved 11 February 2018). 
Rome Statute of the International Criminal Court, available at: https://www.icc-cpi.int/nr/ rdonlyres/ea9aeff7-5752-4f84-be94-0a655eb30e16/0/rome_statute_english.pdf (retrieved 11 February 2018).

Rossiiskoe grazhdanskoe parvo: T. II [Russian Civil Law: Vol. II] (2014). Ed. by E.A. Sukhanov. Moscow, Statut, 1207 p.

\title{
Конституционная обязанность государства обеспечить компенсацию ущерба, причиненного потерпевшим
}

\author{
В.Ю. Панченко, А.Е. Михалева \\ Сибирский федеральный университет \\ Россия, 660041, Красноярск, пр. Свободный, 79
}

\begin{abstract}
Рассматривается статья 52 Конституичии Российской Федераџии, в соответствии с которой государство обязано обеспечить потерпевшим от преступлений компенсацию причиненного ущерба. С одной стороны, многие исследователи полагают, что на сегодняшний момент позитивное обязательство государства по данной статье ограничивается созданием необходимых законодательных и правоприменительных механизмов, которые обеспечивают розыск активов, арест имущества и другие условия, необходимые для обеспечения возмещения вреда виновныл лицом. С другой стороны, по мнению авторов, статья 52 Конституции Российской Федерации имеет самостоятельное значение, поднимая вопрос о возможных способах восстановления справедливости в тех случаях, когда государство не является причинителем вреда, но никто другой не возместит ущерб потерпевщему. Эта позиция учитывает прогрессивный международный опыт и острую соииальную необходимость существования такой альтернативы в демократическом обществе. Однако при последовательном применении различных способов толкования к исследуемой норме авторы приходят к выводу, что закрепляемое ею право является иллюзорным, так как механизмов его реализации законодательством не предусмотрено. Подобная ситуация подрывает значение Конституичи как основополагающего акта, обладающего высшей юридической силой. Поэтому могут быть предложены три способа преодоления данной ситуации: внести изменения в текст Конституции Российской Федерачии и отказаться от неоднозначной формулировки; полагаться на прямое действие Конституции Российской Федераџии при правоприменении; принять закон, конкретизирующий порядок обеспечения государством компенсации ущеебба потерпевщим от преступлений. Следовательно, вопрос реализации статьи 52 требует незамедлительного решения на высшем политико-правовом уровне.
\end{abstract}

Ключевые слова: конституционные права и свободы, юридические гарантии, позитивные обязательства, компенсация ущерба, причиненного потерпевщим от преступлений.

Статья подготовлена при финансовой поддержке гранта Президента Российской Федераиии № МД-721.2018.6.

Научная спещиальность: 12.00.00 - юридические науки. 